\title{
Russian Foreign Policy and Public Diplomacy: Meeting 21st Century Challenges
}

\author{
G. Simons \\ Uppsala University, Uppsala, Sweden \\ Turiba University, Riga, Latvia \\ Ural Federal University, Yekaterinburg, Russian Federation
}

\begin{abstract}
Foreign policy is about setting the policy aims and goals of a given country in the competitive environment of international affairs. When analyzing it, one should pay attention to many factors, namely, economic and energy potential, military-technical means, the presence of trade and economic partners, political weight and state image in the international arena, state membership in various international organizations. You can also highlight a number of tools that also play a large role in the foreign policy of states. As a specific instrument of foreign policy, public diplomacy concerns the regulation and management of international relations with various global publics in order to realise those foreign policy aims and goals. Specifically, public diplomacy intends to create a positive reputation and brand of the country, simultaneously increasing the country's soft power potential, which is based on external and internal sources. This article intends to track and analyse the challenges and the role played by Russian public diplomacy in terms of meeting the challenges of the country's foreign policy agenda in the 21 st century. These challenges have been in a state of transformation as the nature of the environment of international relations changed. As a result, Russian public diplomacy has needed to evolve along with the changes at the global level and consequently the shifting demands enshrined in the foreign policy concepts. There are several identified distinct political policy periods noted: attempts to integrate into the Western-led global order; cooling relations with the United States dominated global order; and preparing for multi-polar and a post-Western global order.
\end{abstract}

Key words: Russia, foreign policy, public diplomacy, international relations, global order, multi-polarity

Acknowledgements: The reported study was funded by the Russian Science Foundation grant No. 19-18-00264.

For citation: Simons, G. (2020). Russian Foreign Policy and Public Diplomacy: Meeting 21 st Century Challenges. Vestnik RUDN. International Relations, 20 (3), 491-503. DOI: 10.22363/2313-0660-2020-20-3-491-503

\section{Внешняя политика России и публичная дипломатия: вызовы XXI века}

\author{
Г. Симонс \\ Университет Упсалы, Упсала, Швеция \\ Университет Туриба, Рига, Латвия \\ Уральский федеральный университет им. первого Президента России Б.Н. Ельцина, \\ Екатеринбург, Российская Федерация
}

Внешняя политика представляет собой установление политических целей и задач данной страны в конкурентной среде международных отношений. При ее анализе следует обращать внимание на множество

(C) Simons G., 2020

This work is licensed under a Creative Commons Attribution 4.0 International License.

https://creativecommons.org/licenses/by/4.0/ 
факторов, а именно на экономический и энергетический потенциал, военно-технические средства, наличие торгово-экономических партнеров, политический вес и государственный имидж на международной арене, членство государства в различных международных организациях. Также можно выделить и ряд инструментов, которые также играют большую роль во внешнеполитической деятельности государств. Как конкретный инструмент внешней политики публичная дипломатия касается регулирования и управления международными отношениями с различными мировыми акторами с целью реализации этих целей и задач внешней политики. В частности, публичная дипломатия призвана создать положительную репутацию и бренд страны, одновременно увеличивая потенциал страны в области «мягкой силы», который основывается на внешних и внутренних источниках. Статья призвана отследить и проанализировать проблемы и роль, которую играет российская публичная дипломатия в плане решения задач внешней политики страны в XXI в. Эти проблемы находились в состоянии трансформации по мере изменения характера среды международных отношений. В результате российская публичная дипломатия должна развиваться вместе с изменениями на глобальном уровне и, следовательно, меняющимися требованиями, закрепленными в концепциях внешней политики. Отмечено ее развитие на нескольких этапах: попытке интегрироваться в западный мир, охлаждение отношений с США, доминирующими на мировой арене, и подготовка к многополярному и постзападному глобальному порядку.

Ключевые слова: Россия, внешняя политика, публичная дипломатия, международные отношения, мировой порядок, многополярность

Благодарности: Статья подготовлена в рамках исследовательского гранта Российского научного фонда, проект № 19-18-00264.

Для цитирования: Simons $G$. Russian Foreign Policy and Public Diplomacy: Meeting 21st Century Challenges // Вестник Российского университета дружбы народов. Серия: Международные отношения. 2020. Т. 20 . № 3. C. 491-503. DOI: $10.22363 / 2313-0660-2020-20-3-491-503$

\section{Introduction}

An increasing amount of attention is paid to Russian foreign policy and public diplomacy in the 21 st century. Molchanov notes that the study of Russian foreign policy has sometimes given rise to a number of myths and misconceptions, which can fail to take into account cultural aspects and factors into account [Molchanov 2015: 50].

There are different foci by foreign (i.e. non-Russian) researchers that are researching and publishing on these issues. One of the tracks is to treat Russian foreign policy and/or public diplomacy as a mechanism of neo-imperial ambition [Lucas 2008; Ismayilov 2011]; another path is to treat these aspects as subversive persuasion and/or an element of "hybrid war" [van Herpen 2016; Fox, Rossow 2017]; and another path is that of pursuing national interests and goals from a lens of foreign policy realism ${ }^{1}$. Different biases and miscalculations in Western

\footnotetext{
1 Mearsheimer J.J. Why the Ukraine Crisis is the West's Fault: The Liberal Delusions that Provoked Putin // Foreign Affairs. 2014. Vol. 93. No. 5. P. 77-89. See also: [Kissinger 2015].
}

analysis and assessments of Russian foreign policy create different misperceptions [Gunitsky, Tsygankov 2018]. These various assessments and characterisations of Russian foreign policy and public diplomacy tend to obscure the rapid and wide-ranging change and evolution that has taken place in a short space of time.

This article intends to focus on these remarkable changes and challenges that have been faced by Russian foreign policy and public diplomacy in the 21 st century so far. In order to do this in an orderly and accurate manner and make sense of the trends and developments, it is necessary to take a systematic approach to studying and analysing the bigger picture of the wider political and global environments that influence the challenges and changes. A specific research question is posed - how has Russian public diplomacy evolved to meet the new challenges of the 21 st century?

On the way to answering this research question, the paper shall begin with mapping and analysing the changes and transformations of the global order that have taken place after the Cold War. These rapidly transforming worlds of 
geopolitics and global hegemony have impacted on setting the tasks and goals of Russian foreign policy and the decision-making calculations of the state to identify what is needed in terms of policy direction. The next section looks more closely at the formulations and prioritisation of foreign policy goals through examining the texts of the Russian foreign policy concept documents of the 21 st century. In the third and final section, there is a description and an analysis of public diplomacy's role in meeting the Russian foreign policy challenges.

\section{Russian Foreign Policy Transformations}

In the end of 1991, the collapse of the Soviet Union and the Eastern Bloc fundamentally altered the global geopolitical balance and saw a sudden shift from a bipolar world order (United States and the Soviet Union) to a unipolar order as the United States was the sole remaining superpower. This had a very sudden and profound impact on international relations and politics (including the foreign policy) in the newly emergent Russian Federation. Among these significant changes were the freeing of foreign policy from ideological pressures and influences, such as the principles of proletarian and socialist internationalism. In practice this meant a redefinition and reconfiguration of allies and clients in the international system, and the ability to follow a more pragmatically oriented path of aims, objectives and interests [Molchanov 2015: 51]. It also ushered in a period of instability of foreign policy and international identity trajectories.

The collapse of the Soviet Union brought about a period of political crisis and power struggle by competing groups and ideas. This extended into the foreign policy area, where various foreign policy concepts and philosophies were promoted by politically active groups that sought attention and influence in a highly contested political environment [Arbatov 1993]. Russia's foreign policy began with a short period around 1992-1993, when there was a proWestern Atlanticist phase where there was somewhat uncritical collaboration with the West. This witnessed what seemed like an embrace of US leadership in the post-Cold War world and an acceptance of the new unipolar global order [Yasmann 1993; Kumar 2018: 213-216].

However, the unabated expansion of NATO eastwards and Russia not having their interests heard or respected, a new foreign policy orientation and identity followed. The period of neo-Eurasianist orientation occurred in the mid-late 1990s as the differences between the West and Russia increased, lasting until the arrival of Vladimir Putin [Cox 2000; Molchanov 2015: 51; Tsygankov 2016: 59-133]. NeoEurasianism was the result of a lack of acceptance of Russia as a partner or an equal, and a lack of acceptance into economic and military-political organisations, which was a mixture of geopolitics and a civilizational approach [Kubyshkin, Sergunin 2015: 32]. This foreign policy identity and vector can also be seen as a counteraction to what was perceived as US unilateralism by introducing a degree of multilateralism [Ambrosio 2001]. When Boris Yeltsin chose Vladimir Putin to be his successor, yet another change was ushered in.

In the opening years of Vladimir Putin's presidential rule, a national-pragmatist approach to foreign policy was adopted. Some Western observers noted Vladimir Putin's initial arrival with enthusiasm and a chance to align Russia's foreign policy identity and choices with the West $^{2}$. This included an active search in diversifying international allies and partners through a multi-vector approach, balancing East and West. During this brief period, which included another rapprochement with the U.S. in the wake of the $9 / 11$ attacks and seeking membership to Western dominated international organisations as the G8 and the World Trade Organisation. Foreign policy was guided and conducted more by results-based interests, rather than by great power identity [Molchanov 2015: 52; Tsygankov 2016: 135-176]. However, foreign policy has continued to evolve and change over time.

A second phase of the national-pragmatist approach has been identified with a Russian

\footnotetext{
${ }^{2}$ Legvold R. All the Way: Crafting a US - Russia Alliance // The National Interest. Winter 2002/03. No. 70. P. 2.
} 
pivot towards Asia as relations with the U.S.-led West continued to deteriorate and decline. This was in part a result of China's continuing global rise as a global economic power, but also the result of the Colour Revolutions and the Western entry into post-Soviet space via regime changes. These "revolutions" and NATO's expansion were seen as a direct challenge to Russian interests in the "Near Abroad"3. Furthermore, in the wake of the 2008 Georgian-Russian War there was the recurring feeling of an unequal and imposed partnership on Russia by the West. "Russia has shown to the West that the partnership model imposed upon it, built on hypocrisy and ambiguity, cannot work any longer"4. This signalled a shift in perception and policy, not only at the regional level, but the global as well. Yet another phase of the national pragmatism has been identified.

$A$ third and current form of national pragmatism in Russian foreign policy has been noted. The 2008 Georgian-Russian War was a pivotal moment in terms of creating a more defined Russian path in terms of its foreign policy. In terms of official rhetoric there is a drive to create a real global multipolarity, rather than a declared one. "The backbone elements are Moscow's refusal to stick to the rules of the game laid down by the West and its readiness to oppose the West, at least in some aspects that have bearing on Russia's fundamental interests, even at the cost of a serious confrontation"5.

This new path has a more regionalist and multilateral approach to its conception and conduct. This is another diversifying of geopolitical (Ukraine and Syria for example) and

3 Kosachev K. Russian Foreign Policy Vertical // Russia in Global Affairs. 2004. No. 3. URL: https:/eng.globalaffairs.ru/articles/russian-foreign-policyvertical/ (accessed: 13.04.2020). See also: [Molchanov 2015: 52-53; Tsygankov 2016: 177-207; Berryman 2018: 70; Mazloomi, Yeoh, Karim 2018].

${ }^{4}$ Aksenyonok A. Paradigm Change in Russian Foreign Policy // Russia in Global Affairs. 2008. No. 4. URL: https://eng.globalaffairs.ru/articles/paradigm-change-inrussian-foreign-policy (accessed: 13.04.2020).

5 Lukin A. From a Post-Soviet to a Russian Foreign Policy // Russia in Global Affairs. 2008. No. 4. URL: https://eng.globalaffairs.ru/articles/from-a-post-soviet-to-arussian-foreign-policy (accessed: 13.04.2020). geo-economic (Eurasian Union and BRICS, but also Nord Stream II, for example) goals and interests, and a rebalancing of threats and opportunities [Molchanov 2015: 53; Svarin 2016; Tsygankov 2016: 233-259; Kumar 2018: 218-219; Ziegler 2018: 131-132]. As a medium-sized great power in global politics and international relations, Russia intends to work within multilateral institutions as a means to justify its actions and to increase its engagement in certain regions. Therefore, multilateralism is Russian foreign policy serves as both a tool and a value [Lee 2010]. These different phases of foreign policy identity and direction are related to adapting to the domestic political and economic environment as well as the wider political and geopolitical aspects of processes and trends occurring in the global order.

\section{Transformations of the Global Order}

In the above text, the different Russian foreign policy identities and trajectories are identified. However, these do not occur in vacuum, different environmental factors, and aspects of the time at the national, regional and global levels shape them. During the rapid success of 1989-1991, the US developed the attitude of a triumphant victor that created the trap of a number of illusions, such as the "end of history", a "unipolar world" and the universality of liberal values. As such the U.S. developed an approach of exploiting the situation through short-term tactics rather than strategic long-term goals $^{6}$. The Soviet Union's rapid collapse left the newly emergent Russia in a weakened state with a fraction of the capacity and capability to project its power and influence globally in the unipolar global order. Therefore, hard and painful choices in budgetary and policy prioritisation were forced upon the Russian Federation. As early as 1993 , a prediction was noted on the possible future of Russian foreign policy: "After the resolution of the current crisis at home, Russian foreign policy most probably will shift from the pro-Western paradigm that

\footnotetext{
${ }^{6}$ Ivanov I. What Diplomacy Does Russia Need in the 21st Century? // Russia in Global Affairs. 2011. No. 4. URL: https://eng.globalaffairs.ru/articles/what-diplomacydoes-russia-need-in-the-21st-century/ (accessed: 13.04.2020).
} 
dominated during 1992 - 1993 to a centrist or moderate-conservative position. It will become more assertive as to Russia's national interests, prestige, and independent role in regional and global affairs. This policy line may cause some tensions with the West but will get greater acceptance and broader support at home" [Arbatov 1993: 41].

The aftermath of the collapse of the bipolar Cold War order to the post-Cold War US unipolar world order left Russia with very few realistic operational alternatives in the immediate short term owing to the economic, social and political chaos. However, as Russia has gained increased strength and stability, although still possessing weaknesses it has become more selfconfident and assertive in its foreign policy as a great power [Tsygankov 2010].

The ignoring of Russian security and status concerns led to a decline in cooperation and trust with the West. This has led to some seemingly contradictory elements: "This is why Russian foreign policy is compensatory and cooperation and non-cooperation coexist. This coexistence can be found in different periods and in Russian policy towards different International Governmental Organisations. Russia instrumentalises different multilateral and bilateral frameworks while pursuing its interests. Second, domestic antiWestern rhetoric is often at variance with Russia's actual politics, through which Russia tries to present itself as a well-behaved, friendly international actor which is, however, aware of its own interests" [Kropatcheva 2012: 38].

The contradictions, as Kropatcheva also notes, can be found and understood in the fact and consequence of communication to different stakeholders by the Russian government (domestic audience and an international audience). Russia's foreign policy challenge to the idea of Westerndictated international relations has itself drawn a response that this needs to be responded to and/or challenged [Aggarwal, Govella 2012]. However, with US global hegemony in retreat and emerging multipolarity, attention is now shifting to the implications of the power shifts in relations between the established powers and rising or emerging centres of power [Berryman 2012: 538]. The background of the decline of the bipolar global order and the rise of the US unipolar order and the subsequent weakening of this unipolar order towards a more multipolar order are needed to bring context to the logic of foreign policy in the international relations environment. Therefore, the foreign policy course of third national-pragmatist model that involves a focus on regionalism and multilateralism is the relevant stance to understand the words and deeds of navigating the transforming global order of the 21 st century.

Foreign Minister Sergey Lavrov, however, noted the unpredictability of the transforming global order. "Today, no one argues that the emerging international system by definition is polycentric... However, no one can say yet what contours the 21 st century world order will take and how stable and efficient it will be"7. The hegemonies of global liberalism in the political realm and the United States in the geopolitical realm are weakened, even though they still remain the dominant forces for now.

However, they are being severely weakened by internal crises that stem from critical failures in the system (social, economic and political). The loss of appeal and universality of these hegemonic systems is becoming increasingly evident through increasing international conflict and competition, such as the so-called New Cold War [Simons, Kukartseva 2019]. This has in turn encouraged other powers to openly contest and challenge these hegemonies, exploiting their weaknesses as an opportunity to gain influence and power at local, regional and global levels. The emerging transformation indicates that the U.S. remains the single most tangibly powerful country, but other lesser non-Western powers are rising at different levels (China, India, Turkey, Russia, Iran, Saudi Arabia and Qatar for example) [Simons 2019]. How do Russia's foreign policy concepts try to make policy and practice sense out of this transforming environment in order to lever its relative strengths and match them with international relations opportunities?

7 Lavrov S. Russia in the 21st Century World of Power// Russia in Global Affairs. 2012. No. 4. URL: https://eng.globalaffairs.ru/articles/russia-in-the-21stcentury-world-of-power/ (accessed: 13.04.2020). 


\section{Foreign Policy Doctrine: Tracking Evolution in Russian Foreign Policy in the 21st Century}

Official concepts, doctrines and blueprints perform a specific set of roles in the realms of politics and international relations. In the 21 st century, Russia pursues a pragmatic and not ideological course in its foreign policy. As such, there is a lack of a specific "guide" to the identity and principles of the foreign policy course.

Therefore, policy makers, intellectuals and practitioners sought a means to articulate foreign policy to reduce ambiguity and increase coherence in meeting the challenges at hand. Light notes these documents "are descriptive rather than prescriptive, and they distinctly lack a sense of 'mission'. They represent an attempt to deal with the end of ideology, rather than an endeavour to create a substitute ideology. They do, however, reflect Russia's current national values, and they represent a continuity in the political culture which the communists inherited from prerevolutionary Russia" [Light 2003: 53]. However, Light also acknowledges a practical aim of the concepts: "They were adopted during a transitional period when Russian policy was in flux. They served to reduce the confusion in the outside world caused by different political actors expressing diametrically opposed views about foreign policy" [Light 2003: 53]. This is communication strategy is about informing the outside world and bringing about a common understanding and consensus in the domestic environment.

Four Foreign Policy Concepts (FPC) of the Russian Federation from the last 20 years have been selected and are examined and analysed, these are from the years 2000, 2008, 2013 and 2016. Texts of these concepts will be scanned to bring to the fore the main expressed foreign policy identities and goals, which is to be referenced back to the earlier mentioned foreign policy identities and courses in the section on Russian Foreign Policy Transformations. This will also be referenced to Light's observations on the role played by concepts.

The first FPC to be examined and analysed was approved by President Vladimir Putin on
June $28,2000^{8}$, a matter of only several months after he was newly elected to office. This came at a time when Russia was emerging from eight years of presidential rule by Boris Yeltsin. Therefore, the significance of this document is that it is the first attempt to articulate the foreign policy identity, direction, priorities and goals after President Yeltsin.

A number of key objectives, priorities and goals were listed in the 2000 FPC. As noted by Light, these were hedged in rather non-specific terms of identifying possible opportunities and threats for Russian interests [Light 2003]. In the text, Russia seeks to reduce US unipolarity and increase multipolarity through international institutions. The first interest was to protect the sovereignty and territorial integrity of Russia, to gain recognition in the world community that is in-line with its great power status. Combined these aspects are intended to serve as a means for Russia to realise its full potential. The other noted interests work towards consolidating this first objective, such as recognising international law and the UN Charter, developing the Russian economy, resolving and removing tensions and hot spots from along the Russian border. An active seeking collaboration and cooperation with other countries based on mutual interests and tasks that coincide with Russian priorities. It mentions to need to actively promote Russian language and culture internationally. Russia is characterised as being a reliable and constructive member of the international community during a period of new challenges and threats to the national interests of Russia are emerging in the international sphere. All of this coinciding at a point in time of fundamental and dynamic changes that are affecting the modern world. Stated objectives included: continued process of globalisation; intensification of the role of international mechanisms in world politics and economics; significance of regionalisation across the globe for security and stability. The priority regions for Russia at this stage were CIS,

\footnotetext{
${ }^{8}$ The Foreign Policy Concept of the Russian Federation (approved by the President of the Russian Federation V. Putin on June 28, 2000). URL: https://fas.org/nuke/ guide/russia/doctrine/econcept.htm (accessed: 13.04.2020).
} 
European Union and US. Of other lesser and varying level of significance and importance are Asia, Middle East, Africa, Central and South America.

The text and rhetoric of the 2000 FPC is in keeping with the first national-pragmatist approach of Putin. This phase included a multivector approach to actively seeking international partners and allies, and in balancing east and west. The membership to multilateral, international and Western dominated organisations is sought for international recognition of Russia and its perceived international position, but there is also the aspect of creating regions of the globe that were of greater or lesser interest that are formed on the basis of concrete pragmatic results tied to Russian interests.

In January 2008 the second FPC was established and replaced the earlier versions ${ }^{9}$. This document is intended to supplement and develop the provisions of the 2000 FPC. The updated FPC was precipitated by developments in the field of international relations in the beginning of the 21 st century and Russia's increased engagement in international affairs. Listed priorities in the beginning of the document remained the same as the previous version of the FPC. This FPC noted that foreign policy became an essential instrument for steady national development and ensuring Russia's competitiveness in a globalising world.

The increased importance and advantages of network diplomacy based on active participation in international structures working towards common solutions to common problems over the traditional military and political alliances. There are still mentions of developing cooperation with the West, but that this is negatively affected by the antagonistic psychological legacy of the Cold War. In addition, other alternative options are being sought simultaneously, such as Asian partners. It was noted often, there is an urgent need for the further development of different forms of public diplomacy and the engagement

\footnotetext{
${ }^{9}$ The Foreign Policy Concept of the Russian Federation (approved by the President of the Russian Federation D. Medvedev on January 12, 2008) // The President of Russia official website. URL: http://en.kremlin.ru/ supplement/4116 (accessed: 13.04.2020).
}

with international publics to influence perception and opinion about Russia and Russians. The CIS remained the priority area for foreign policy, developing relations with the EU countries, US, Muslim countries, Latin America, China, and India featured prominently too.

Although the 2008 FPC was in force before the 2008 Georgian-Russian War, a number of difficulties with NATO, US and EU were noted. There is also an indication of the pivot towards relations with significant Asian countries. This is in line with the second national pragmatist foreign policy identity and course. The elevated importance of public diplomacy's development and use also seems to be a product of the need to reach global publics as formal diplomacy with leading Western powers became increasingly deadlocked and confrontational.

Another FPC was approved in $2013^{10}$, the third of the reviewed documents. The basic priorities that are listed remain the same as in the 2000 and 2008 FPC. One of the significant differences is found in the assessment of the transforming global order: "The ability of the West to dominate world economy and politics continues to diminish. The global power and development potential are now more dispersed and is shifting to the East, primarily to the AsiaPacific region. The emergence of new global economic and political actors with Western countries trying to preserve their traditional positions enhances global competition, which is manifested in growing instability in international relations" 11 . There also mentions of the financial crisis in the West and reactions against the globalisation process (return to civilizational identity in the Middle East North Africa region), and unilateral attempts to manage crises through coercive means (hinting at the US and its allies). The concept of soft power is discussed in relation to the practice of foreign policy. The

10 The Foreign Policy Concept of the Russian Federation (approved by the President of the Russian Federation V. Putin on February 12, 2013) // The Ministry of Foreign Affairs of the Russian Federation. URL: https://www.mid.ru/en/foreign_policy/official_documents/ -/asset_publisher/CptICkB6BZ29/content/id/12 2186

(accessed: 13.04.2020).

11 Ibid. 
increased importance of non-Western dominated international organisations (G20, BRICS and RIC) and Russia's participation is stressed.

The transformation of the global order is openly discussed and the various problems and crisis in and with the West. It is a transformation of competition in global affairs towards a situation of conflict. A desire for collaboration and cooperation is expressed rhetorically, but under the circumstances seems illusive practically speaking. Therefore, Russia's pivot away from the declining Western dominated political and economic global order to a non-Western grouping of rising powers. This is perfectly in keeping with the third form of the national pragmatic model of Russian foreign policy.

In November 2016 the next version of the FPC was approved ${ }^{12}$. The issue of the transforming global order and its consequences were developed further and described more vividly: "The world is currently going through fundamental changes related to the emergence of a multipolar international system. The structure of international relations is becoming increasingly complex. Globalisation has led to the formation of new centres of economic and political power. Global power and development potential are becoming decentralised, and is shifting towards the Asia-Pacific Region, eroding the global economic and political dominance of the traditional Western powers. Cultural and civilizational diversity of the world and the existence of multiple development models have been clearer than ever"13.

However, it is noted that these changes are creating a more chaotic, tense and violent world, and for the first time in these documents, the spectre of large-scale military conflict is not excluded as a possibility. Russia is presented as being open and predictable and playing an ageold role of a counterbalance in international

12 The Foreign Policy Concept of the Russian Federation (approved by the President of the Russian Federation V. Putin on November 30, 2016) // The Ministry of Foreign Affairs of the Russian Federation. URL: $\quad$ https://www.mid.ru/en/foreign_policy/official documents/-/asset_publisher/CptICkB6BZ29/content/id/ 2542248 (accessed: 13.04.2020).

${ }^{13}$ Ibid. affairs and the development of global civilisation. A harder rhetorical stance is made against the words and lack of matching deeds, where both NATO and the EU are held in equally negative regard.

Not only is the issue of the transformation of the global order discussed, the possible scenarios and consequences are also predicted. The transformation is presented as being an irreversible process, which has created a significant increase in violence and instability in global affairs as the current global Western hegemonic order seeks to prevent its demise and the rise of non-Western powers. This signals a gradual hardening of the third form of the national pragmatic line of Russian foreign policy identity and practice.

\section{Public Diplomacy: Meeting Russia's Foreign Policy Challenges}

In 2012, Sergey Lavrov noted one of the weaknesses of Russia in getting its message to the world, developing and building international relationships is related to its underdeveloped use of soft power. This includes Russia's relatively small share of the global information space and under used opportunities in new information communication technologies ${ }^{14}$. However, these elements and aspects of public diplomacy are in the process of being developed in an aggressive and crowded global information environment. In this section, the development of public diplomacy, conceptually and operationally, shall be linked to the three frames of the national pragmatic foreign policy orientation of the $21 \mathrm{st}$ century. The three forms of national pragmatism shall be taken in chronological order, and how public diplomacy was being used to meet the challenges and goals of the international environment and the visions of the relevant FPC.

During the first form of the national pragmatic foreign policy orientation, Russia was emerging from the chaotic Yeltsin years in a U.S.-led unipolar global order and the beginning

14 Lavrov S. Russia in the 21st Century World of Power// Russia in Global Affairs. 2012. No. 4. URL: https://eng.globalaffairs.ru/articles/russia-in-the-21stcentury-world-of-power/ (accessed: 13.04.2020). 
of the Global War on Terrorism. Therefore, the goals as stated in the 2000 FPC were to engage in a multi-vector approach in international relations, which involved an attempt to integrate into Western dominated international organisations, but also to search for a broader base of global partners. A key consideration for public diplomacy's role to achieving these aims was to improve the global image of Russia and Russians through reputation and brand management. This was undertaken as a top-down approach to resolve the matter of Russia's brand and reputation.

A significant obstacle to achieving these aims was found in the fact that Russia has a sticky existing reputation and brand that is hard to overcome, made more difficult through the lack of a consistent and concrete idea of Russian identity, concepts and values expressed and communicated [Just 2016]. Furthermore, the attempts to remake the reputation and brand did not go unchallenged. However, some success of Russian diplomacy and public diplomacy can be noted in terms of admittance to the G8 and World Trade Organisation. This phase concerns the integration and acceptance into the international community as an equal partner and in expanding the international relationships and interactions.

The second variant of the national pragmatic foreign policy vector was the pivot towards Asia and away from the U.S.-led West. This was the result of the culmination of a number of difficulties experienced by Russia in its relations with the West and the lack of acceptance or acknowledgement of Russian interests and various attempts to undermine them (such as the Colour Revolutions). Rising Asian powers, such as China, were seen as having greater potential and reliability than what was perceived as the Western dictates and hypocrisy. Russia's attention and beginning of the consideration of soft power's potential in regulating international affairs came as a result the release of Nye's book during the period of U.S. soft power and the Colour Revolutions in post-Soviet space [Rutland, Kazantsev 2016: 396].

During this period of national pragmatic foreign policy, a number of institutions and assets of public diplomacy and soft power were established such as Valdai Club, RT (Russia Today), Rossotrudnichestvo Russkii Mir, Russian International Affairs Council and the Gorchakov Foundation [Rutland, Kazantsev 2016; Velikaya 2018]. As noted by A. Velikaya: "Unlike the public diplomacy of Western countries Russian public diplomacy is not focused on exporting democracy but is aimed at promoting international dialogue and the strategic stability among various international players" [Velikaya 2018: 39]. Therefore, in this second phase of national pragmatism, the focus of Russian public diplomacy concerns attracting allies and partners, and in creating dialogue with 'difficult' international actors.

The third form of the national pragmatic foreign policy orientation is situated in a highly complex and evolving international environment, which is prone to instability and conflict. Former Foreign Minister Igor Ivanov noted the increased importance of "non-material components" (intangible) for Russia's foreign policy owing to the "material component" (tangible) shortages and relative contextual weakness compared to other international powers. He concluded that this will cause the diminishing opportunities for Russia to make use of traditional tools of foreign policy (such as military and economic power) and increase the use of "smart" policy through engaging international stakeholders via mechanisms of public diplomacy and soft power ${ }^{15}$.

In the third age of national-pragmatism in foreign policy, one of the key roles played by public diplomacy is vying for the hearts and minds of the global publics within bitter and relentless information war that rages between the West and Russia. This can be seen through the various global media of mass communication, where competing sets of norms and values clash in the information space. The relative moments of advantage come when the weaknesses of US and Western policy and narratives become

${ }^{15}$ Ivanov I. What Diplomacy Does Russia Need in the 21st Century? // Russia in Global Affairs. 2011. No. 4. URL: https://eng.globalaffairs.ru/articles/what-diplomacydoes-russia-need-in-the-21st-century/ (accessed: 13.04.2020). 
apparent within a climate of declining trust in public authorities and mainstream media [Simons 2018a]. As part of an effort to acknowledge and work with this challenge as well as begin to follow the suggestions of the FPCs by diversifying the base of actors and stakeholders planning, managing and running public diplomacy programmes [Simons 2018b]. One of the challenges and concerns for Russian diplomacy and a problem for public diplomacy in particular is the often negative and hostile reception in mainstream Western media.

Other alternative means of direct communication with foreign publics were sought; one of the means has been via an active social media presence [Simons 2015]. Social media has enabled Russian public diplomacy to directly reach foreign publics without any intermediaries and reinterpretation by other actors. A. Velikaya states, that "Russian public diplomacy and humanitarian cooperation are focused on the Eurasian region, as well as on the countries disillusioned with the West, searching for a new joint international agenda, countering Western hegemony on setting values (mainly liberal one)" [Velikaya 2018: 59]. Some successes have been noted, such as the Middle East and North African region where Russia has developed a great deal of soft power and influence at the expense of the United States [Morozov, Simons 2019]. The aim of public diplomacy is to rehabilitate the negative international image of Russia in order to generate potential relative advantages in international relations and affairs.

Some situations are taken for granted, such as the importance placed in Russian relations with the CIS countries, some of which are perceived as being pro-Russian. However, this subjective assumption does not relate to the pragmatic economic interests and a multilateral course of some of these countries and the result is a weakening of relations [Petrovich-Belkin, Eremin, Bokeriya 2019]. A mixture of historical memory and a lack of listening (plus various assumptions) also tend to inhibit any meaningful progress of Russian public diplomacy and soft power in the Baltic States [Simons 2015]. This is related to the presumed and actual soft power, which is an element of importance for Russian foreign policy stressed in a number of the FPCs to achieve a relative competitive advantage over more powerful international rivals.

The Russian understanding and application differ from Nye's definition of soft power, which is apparent in the state-centred approach and interests [Simons 2018b: 145-149]. There have been successes of Russian soft power and public diplomacy, especially among mass sporting events, such as the 2014 Sochi Winter Olympic Games and the 2018 Soccer World Cup [Rutland, Kazantsev 2016: 403]. As the global order is currently in a state of flux and chaos, there are many risks as well as opportunities to navigate, which requires a flexible, comprehensive, credible, realistic, longer term and considered approach in order to maximise the possible opportunities that may arise.

\section{Conclusion}

The world of international relations and the state of the global order are undergoing a significant and wide-reaching transformation that is profoundly affecting the way that diplomacy and public diplomacy are conceived and conducted. This paper has focused on the results of Russian diplomacy and public diplomacy for the last 20 years, although needing to occasionally revisit earlier periods of recent history in order to create an understandable and logical contextual social, economic and political environment. An operating environment as this one creates a very challenging environment of varying strengths, weaknesses, threats and opportunities for any international actor.

In the introduction to this paper, a research question was posed. How has Russian public diplomacy evolved to meet the new challenges of the $21 \mathrm{st}$ century? There have been three identified phases of national pragmatist foreign policy approach, each evolving to meet the specific needs and demands created by the wider global trends and processes, but also mindful of the domestic needs and requirement of Russia. This is seen not only in the foreign policy identities and stances, but also in the text of the various foreign policy concepts that are intended 
to serve as a guide to articulate what priorities are important to reduce ambiguity and as a means to demonstrate and communicate to the wider world the current views of the foreign policy course.

Public diplomacy during the first period of national pragmatist foreign policy was involved in supporting the goal of developing a multivector approach that sought to diversify Russia's international partners and to balance east and west. Though, it also sought to reinvigorate a positive image of Russia on the international stage in order to increase its standing and recognition, and to integrate the country into a number of Western dominated international organisations. This was attempted with a relatively underdeveloped conceptual and institutional base.

In the second period of the national pragmatist stance to foreign policy, public diplomacy sought to assist the pivot towards Asia and to defend its interests and influence against Western interference in the post-Soviet area (Colour Revolutions). This did not mean breaking off attempts to engage and interact with the U.S.-led West, but the recognition that Russian interests and priorities were not considered or respected. The move towards closer relations with Asia was a pragmatic consideration in terms of economic considerations and some security matters (SCO and BRICS). This was also an era of the rapid development of foreign policy and public diplomacy concepts, institutions approach that included a desire for a more comprehensive global engagement as a great power. Initially, in this phase, the concepts and practice of public diplomacy communication and interaction was influenced by Western concepts and approaches that were sometimes adapted to meet the specific needs of the time.

The third and current phase of the national pragmatic approach to foreign policy is set in a highly volatile and conflict-ridden global environment. There is an open call for multipolarity in a global order that is transitioning from a unipolar to a multipolar configuration. In terms of the role of public diplomacy, there is greater use of multilateral organisations to justify Russia's stance and to criticise the U.S.-led stance, such as the United Nations (in particular the UN Security Council). There is an attempt by public diplomacy to develop global regions as a means of opportunely challenging U.S. hegemony, such as in the Middle East North African region.

Russia's soft power and influence is very unevenly distributed globally, some publics and regions are more receptive than others, and often influenced by wider global geopolitical and geoeconomic factors and considerations. Russian public diplomacy has also been actively developing its ability to directly reach global publics as traditional state to state diplomacy becomes deadlocked and Western mass media tend to be hostile to Russia. This has been found in the digital world of social media where the dynamics of communication and interaction are challenging, but potentially paying dividends in the medium to longer term. One of the remaining constraints on the success of Russian public diplomacy is found in the lack of a clear and coherent set of clear and compelling messages concerning basic issues as Russia's place in the world, an understanding of identity and values of Russia and Russians.

Received / Поступила в редакцию: 30.04.2020 Accepted / Принята к публикации: 10.06.2020

\section{References / Библиографический список}

Aggarwal, V.K. \& Govella, K. (Eds.). (2012). Responding to a Resurgent Russia: Russian Policy Responses from the European Union and the United States. New York: Springer.

Ambrosio, T. (2001). Russia's Quest for Multipolarity: A Response to US Foreign Policy in the Post-Cold War Era. European Security, 10 (1), 45-67. DOI: 10.1080/09662830108407482

Arbatov, A.G. (1993). Russia's Foreign Policy Alternatives. International Security, 18 (2), 5-43. DOI: $10.2307 / 2539096$ 
Berryman, J. (2012). Geopolitics and Russian Foreign Policy. International Politics, 49 (4), 530-544. DOI: $10.1057 /$ ip.2012.15

Berryman, J. (2018). Geopolitics. In: Tsygankov, A.P. (Eds.). Routledge Handbook of Russian Foreign Policy. London: Routledge. P. 60-78.

Cox, M. (2000). From the Cold War to Strategic Partnership? US-Russian Relations Since the End of the USSR. In: Bowker, M. \& Ross, C. (Eds.). Russia after the Cold War. Singapore: Pearson Education Limited. P. $258-279$.

Fox, A.C. \& Rossow, A.J. (2017). Making Sense of Russian Hybrid Warfare: A Brief Assessment of the RussoUkrainian War. The Land Warfare Papers, 112, 1-23. URL: https://www.ausa.org/sites/default/files/ publications/LWP-112-Making-Sense-of-Russian-Hybrid-Warfare-A-Brief-Assessment-of-the-RussoUkrainian-War.pdf (accessed: 12.02.2020).

Gunitsky, S. \& Tsygankov, A.P. (2018). The Wilsonian Bias in the Study of Russian Foreign Policy. Problems of Post-Communism, 65 (6), 385-393. DOI: 10.1080/10758216.2018.1468270

Ismayilov, E. (2011). How Neo-Imperial Is Russia: Neo-Imperialism in the Foreign Policy of Russia Towards PostSoviet Countries. Saarbrucken: VDM Verlag Dr Muller.

Just, T. (2016). Promoting Russia Abroad: Russia's Post-Cold War National Identity and Public Diplomacy. The Journal of International Communication, 22 (1), 82 — 95. DOI: 10.1080/13216597.2015.1123168

Kissinger, H. (2015). World Order. New York: Penguin Books.

Kropatcheva, E. (2012). Russian Foreign Policy in the Realm of European Security Through the Lens of Neoclassical Realism. Journal of Eurasian Studies, 3 (1), 30 - 40. DOI: 10.1016/j.euras.2011.10.004

Kubyshkin, A. \& Sergunin, A. (2015). The Problem of the "Special Path" in Russian Foreign Policy (From the 1990s to the Early Twenty-First Century). Russian Social Science Review, 56 (3), 31-42. DOI: 10.1080/ 10611428.2015 .1070628

Kumar, R. (2018). Russia's Foreign Policy: An Overview of 25 Years of Transition. International Studies, 53 (3-4), 210-226. DOI: 10.1177/0020881717745961

Lee, H. (2010). Multilateralism in Russian Foreign Policy: Some Tentative Evaluations. International Area Review, 13 (3), 31-49. DOI: $10.1177 / 223386591001300302$

Light, M. (2003). In Search of an Identity: Russian Foreign Policy and the End of Ideology. Journal of Communist Studies and Transition Politics, 19 (3), 42-59. DOI: 10.1080/13523270300660017

Lucas, E. (2008). The New Cold War: Putin's Russia and the Threat to the West. New York: Palgrave MacMillan.

Mazloomi, E., Yeoh, E. K-K. \& Karim, M.A. (2018). From Status Inconsistency to Revisionism: Russian Foreign Policy After Colour Revolutions. Japanese Journal of Political Science, 19 (3), 489-506. DOI: 10.1017/ S1468109918000142

Molchanov, M.A. (2015). Eurasian Regionalisms and Russian Foreign Policy. Farnham: Ashgate.

Morozov, V. \& Simons, G. (2019). Russia's Public Diplomacy in the Middle East. In: Velikaya, A. \& Simons, G. (Eds.). Russia's Public Diplomacy: Evolution and Practice. London: Palgrave MacMillan. P. 233-256.

Petrovich-Belkin, O.K., Eremin, A.A. \& Bokeriya, S.A. (2019). The Decline of Russia's Influence in the PostSoviet Region and the Reasons Behind it. Comparative Politics Russia, 10 (3), 95-104. DOI: 10.24411/22213279-2019-10032

Rutland, P. \& Kazantsev, A. (2016). The Limits of Russia's 'Soft Power'. Journal of Political Power, 9 (3), 395-413. DOI: 10.1080/2158379X.2016.1232287

Simons, G. \& Kukartseva, M.A. (2019). New Cold War and the Crisis of the Liberal Global Order. Outlines of Global Transformations: Politics, Economics, Law, 12 (3), 77-93. DOI: 10.23932/2542-0240-2019-12-3-77-93

Simons, G. (2015). Perception of Russia's Soft Power and Influence in the Baltic States. Public Relations Review, 41 (1), 1-13. DOI: 10.1016/j.pubrev.2014.10.019

Simons, G. (2018a). Media and Public Diplomacy. In: Tsygankov, A.P. (Eds.). Routledge Handbook of Russian Foreign Policy. London: Routledge. P. 199-216.

Simons, G. (2018b). The Role of NGO's in New Public Diplomacy. Journal of Political Marketing, 17 (2), 137-160. DOI: $10.1080 / 15377857.2018 .1447755$

Simons, G. (2019). Digital Communication Disrupting Hegemonic Power in Global Geopolitics: New Media Shape New World Order. Russia in Global Affairs, 17 (2), 108-130. DOI: 10.31278/1810-6374-2019-17-2-108-130

Svarin, D. (2016). The Construction of 'Geopolitical Spaces' in Russian Foreign Policy Discourse Before and After the Ukraine Crisis. Journal of Eurasian Studies, 7 (2), 129—140. DOI: 10.1016/j.euras.2015.11.002

Tsygankov, A.P. (2010). Russia's Power and Alliances in the 21st Century. Politics, 30 (1), 43-51. DOI: 10.1111/ j.1467-9256.2010.01392.x 
Tsygankov, A.P. (2016). Russia's Foreign Policy: Change and Continuity in National Identity. Lanham, MD: Rowman and Littlefield.

Van Herpen, M. (2016). Putin's Propaganda Machine: Soft Power and Russian Foreign Policy. Lanham, MD: Rowman \& Littlefield.

Velikaya, A.A. (2018). The Russian Approach to Public Diplomacy and Humanitarian Cooperation. Rising Powers Quarterly, 3 (3), 39-61. URL: https://risingpowersproject.com/wp-content/uploads/2019/01/vol3.3-velikaya.pdf (accessed: 13.04.2020).

Yasmann, V. (1993). Five Different Perceptions on the Future of Russian Foreign Policy. Demokratizatsiya, 4, $84-95$.

Ziegler, C.E. (2018). Diplomacy. In: Tsygankov, A.P. (Eds.). Routledge Handbook of Russian Foreign Policy. London: Routledge. P. 123-137.

About the author: Simons Greg - Associate Professor, Researcher, the Humanitarian Institute at Ural Federal University in Russia; Researcher, the Institute for Russian and Eurasian Studies (IRES), Uppsala University, Sweden; Lecturer, the Department of Communication Science, Leading Researcher, the Business Technology Institute, Turiba University, Riga, Latvia (e-mail: gregmons@yahoo.com).

Сведения об авторе: Симонс Грэг - доцент, научный сотрудник Уральского гуманитарного института Уральского федерального университета им. первого Президента России Б.Н. Ельцина в Екатеринбурге, Российская Федерация; научный сотрудник Института российских и евразийских исследований Университета Упсалы, Швеция; доцент кафедры коммуникационных наук, ведущий научный сотрудник Института бизнес-технологий Университета Туриба, Рига, Латвия (e-mail: gregmons@yahoo.com). 